\title{
Tobacco waste hydrolysate of stem and root of the tobacco plant for biostimulation in rice and corn seed germination
}

\author{
Paulo Roberto Fetter ${ }^{1}$ (i) Manuela Gassen ${ }^{2}$ (i) Lucélia Hoehne $^{3}$ (i) Michele Hoeltz $^{1,2}$ (i) \\ Lisianne Brittes Benitez ${ }^{1,2}$ (i) Rosana de Cassia de Souza Schneider ${ }^{\left.1^{*}, \mathbb{C}^{(}\right)}$
} 'Programa de Pós-graduação em Tecnologia Ambiental, Universidade de Santa Cruz do Sul (Unisc), 96815-900, Santa Cruz do Sul, RS, Brasil.
E-mail: rosana@unisc.br. "Corresponding author.
'Centro de Excelência em Produtos e Processos Oleoquímicos e Biotecnológicos (CEPPOB), Parque Científico e Tecnológico Regional
(TECNO), Universidade de Santa Cruz do Sul (UNISC), Santa Cruz do Sul, RS, Brasil.
${ }^{3}$ Programa de Pós-graduação em Biotecnologia, Universidade do Vale do Taquari (Univates), Lajeado, RS, Brasil.

ABSTRACT: Stimulation of seed germination may be due to acceleration of germination as well as due to seedling growth-promotion during early development. Plant hydrolysate can be applied as a stimulant. Thus, we aimed to verify the influence of the hydrolysates, obtained by alkaline or acid treatment, from tobacco (Nicotiana tabacum L.) crop residues (root and stem) on the seed germination process. Seed germination was studied with Oryza sativa (rice) and Zea mays (corn). Sixteen germination experiments of 50 seeds each were undertaken, with 4 replicates, soaked with hydrolysates diluted at 20 and $80 \%$, in 2 and $3 \mathrm{~mL}$ of hydration volumes for 48 h. Germinated seeds were counted, at which point radicular protrusions were observed. Rootlets and aerial parts were collected, dried and weighed. The hydrolysates presented seedling nutrition potential to the corn, with $\sim 50 \%$ more mass compared to the results with water at the same conditions, and the germination acceleration was not significant. For the tested rice seeds, the results were reversed, and the germination acceleration was significant with rates up to $94 \%$ after 48 h of incubation. Better results of germination were obtained with hydrolysate from acid treatment, and root or stem tobacco can be used for this purpose.

Key words: Nicotiana tabacum, Oryza sativa, Zea mays, hydrolysates, germination stimulation.

Hidrolisado de resíduo de caule e raiz da planta tabaco para bioestimulação na germinação de sementes de arroz e milho

RESUMO: A estimulação da germinação das sementes pode ser devida à aceleração da germinação, bem como à melhoria do crescimento das mudas durante o desenvolvimento inicial. O hidrolisado de plantas pode ser aplicado como estimulante. Assim, objetivou-se verificar a influência dos hidrolisados, obtidos por tratamento alcalino ou ácido, dos resíduos da cultura do tabaco (Nicotiana tabacum L.) (raiz e caule) no processo de germinação das sementes. A germinação das sementes foi estudada com Oryza sativa (arroz) e Zea mays (milho). Foram realizados dezesseis experimentos de germinação de 50 sementes cada, com 4 repetições, hidratadas em hidrolisados diluídos a 20 e $80 \%$, em 2 e $3 \mathrm{~mL}$ de volumes de hidratação por $48 \mathrm{~h}$. As sementes germinadas foram contadas, momento em que foram observadas protrusões radiculares. Radículas e partes aéreas foram coletadas, secas e pesadas. Os hidrolisados apresentaram potencial nutricional de plântulas para o milho, com 50\% a mais de massa quando comparados aos resultados com água nas mesmas condições, e a aceleração da germinação não foi significativa. Para as sementes de arroz testadas, os resultados foram contrários e a aceleração da germinação foi significativa com taxas de até $94 \%$ após 48 h de incubação. Melhores resultados de germinação foram obtidos com hidrolisado a partir do tratamento ácido, e a raiz ou caule de tabaco pode ser utilizado para esse fim.

Palavras-chave: Nicotiana tabacum, Oryza sativa, Zea mays, hidrolisados, estimulação da germinação.

\section{INTRODUCTION}

The world population has grown since the 1950s; and consequently, agricultural frontiers have expanded, with new planting techniques, investment in genetic improvements, increase of productivity, and more disease resistance (COLLA et al., 2015; DU JARDIN, 2015). Reduction of environmental impacts is also important, and new bioproducts appropriate for agriculture treatment, such as biostimulants for growth and germination, are being studied and used in field scenarios (ABBOTT et al., 2018). 
Biostimulants accelerate the germination process and improve the culture, helping crop establishment by reducing competition between crops and invasive plants, reducing agrochemical use, anticipating the maturation process for the harvest, and reducing negative environmental impacts while maintaining economic sustainability of agricultural systems (RATHORE et al., 2009; SANTOS et al., 2014). Additionally, they enhance crop development from seed germination or plant nutrition, which improves plant adaptability to diverse abiotic stress (MASONDO et al., 2018).

Thus, the use of the substances from renewable sources such as biostimulants may increase the effectiveness of conventional mineral fertilizer or even lessen the requirement for fertilizers. In general, biostimulants consist of humic substances, protein hydrolysate and amino acid formulations, seaweed extract, and plant growth-promoting microorganisms (HALPERN et al., 2015).

Protein hydrolysate $(\mathrm{PH})$ is indicated to be applied as a foliar spray and in seed treatment (DU JARDIN, 2012). According to UGOLINI et al. (2015), PH containing free amino acids and oligopeptides and nonprotein compounds. This previous study used sunflower defatted meal for $\mathrm{PH}$ production by enzymatic transformation and obtained products that were rich in free amino acids and other compounds, with positive effects on the elongation of Zea mays roots.

Bioproducts containing amino acids and oligopeptides applied to cultivation can be important for reducing transplant and oxidative stress as well as for increasing yield (LUCINI et al., 2015). Therefore, amino acids and low-weight molecular peptides from $\mathrm{PH}$ are recognized to provide hormone-like activity and increase nitrogen assimilation (COLLA et al., 2014). Among other ways to exploit these properties, new strategies such as using the hydrolysate residue of several plants have been evaluated in germination and plant nutrition (LUCINI et al., 2015).

According to MOTGHARE et al. (2016), a 16,423 kha area generates $95.512 \mathrm{kt} \mathrm{year}^{-1}$ of vegetable residue, which has abundant availability and low cost. Tobacco residues are a promising source for obtaining biostimulants. First, the plants are not fully utilized, and the stems and roots often remain in the soil, as well as the endless commercial leaves; furthermore, tobacco is cultivated on a large scale around the world, especially in Asia, Africa and Brazil.

In southern Brazil (Rio Grande do Sul, Santa Catarina and Paraná), tobacco crops occupied approximately 360 thousand to 297 thousand hectares, in which there were on average 18,000 feet/ hectare that corresponded to $2365 \mathrm{~kg} \mathrm{ha}^{-1}$ of leaf, according to data from the 2016 harvest (KIST et al., 2018). Furthermore, Brazil is one of the leaders in the production of cigarettes (FORNASIER et al., 2018; CARVALHO et al., 2019).

The amount of wasted stems and roots can sustain the use of these residues as raw material to produce new manufactured products. The obtained compounds or mixtures can aid in the development of agriculture. Tobacco diversification is also important, as the sector is reinventing itself in response to the movement in the WHO Framework Convention on Tobacco Control, against which there will be more significant challenges from the Convention of the Parties (COP 8) of the countries that signed the treaty in Geneva, Switzerland, in October 2018 (KIST et al., 2018; WHO, 2018) . Considering this, four countries are already producing and studying energetic tobacco (Solaris) used for oil seed extraction and other products besides those for smoking. The stems and roots from tobacco Solaris should also be harnessed (SUNCHEM, 2018).

As a result, this research topic is promising, as raw materials are abundant, and there is an opportunity to investigate a new hydrolyzed product from tobacco that could be applied as a germination biostimulant. The exploitation of stem and roots from tobacco could allow an improvement in seed germination and reduce the possibility of diseases. It can be achieved by removal of these residues from the soil, avoiding the perpetuation of pathogenic agents until the next harvest. Therefore, the production of biostimulants from tobacco residue can generate greater economic gain for the tobacco farmer and, in addition, reduce the use of agrochemicals.

In an exploratory study, we aimed to produce biostimulants by acid and alkaline hydrolysis from residues of tobacco (stem and root) and to evaluate their influence on the germination of the Oryza sativa and Zea mays seeds.

\section{MATERIAS AND METHODS}

\section{Hydrolysate preparation}

Tobacco stems and roots from two crops were used in the hydrolysis. The biomass was collected immediately after leaf harvest. The samples were washed, oven dried and comminuted in a knife mill and sieved using 20 to 80 mesh.

In the production of the hydrolysates from the biomass (stem plus root), the following steps were used: acid hydrolysis, vacuum filtration and $\mathrm{pH}$ 
correction $(\mathrm{pH}=7)$. A previous study with different acid and base concentrations was performed in which the use of $1 \%$ of sulfuric acid (acid attack) or sodium hydroxide (alkaline attack) was defined. The temperature was $121^{\circ} \mathrm{C}$ in the autoclave for $60 \mathrm{~min}$, with $10 \%$ load in relation to biomass and solution. The selected conditions were used to prepare hydrolysates for the germination step with biomass separated from root and stem. Alkaline hydrolysis was accomplished only with $1 \% \mathrm{NaOH} / 60 \mathrm{~min}$, using the same procedure (QING et al., 2017).

\section{Germination experiment}

Seeds of Oryza sativa L. (rice) and Zea mays (maize) were randomly selected and separated into 16 batches of 50 seeds each before being packed in previously identified (origin, species, number experiment, solution concentration, hydration and incubation time) plastic containers with a transparent lid.

The experimental design $3^{2}$ was accomplished by testing different immersion volumes, hydrolysate dilutions and incubation times. The seeds were immersed in the hydrolysates diluted in water (20 and $80 \%$ ), with volumes of 2 and $3 \mathrm{~mL}$ for 48 $\mathrm{h}$ according to the Brazilian Rules for Seed Analysis (RAS). For each substrate, special paper (germitest) was used, previously soaked in water in the proportion of 3.0 times the weight of the dry substrate. The seeds were distributed in proportions of $5 \times 10$ totaling 50 seeds per sheet of paper (moistened).

After the sheets were wrapped in cartridge form, they were packed in transparent plastic bags to avoid contact and interference between experiments. Then, the bags were placed in transparent plastic boxes with lids and placed in the germinating chamber, prestabilized at $25{ }^{\circ} \mathrm{C}$ for $24 \mathrm{~h}$. For the conduced photoperiod, artificial light was used from fluorescent lamps $(160 \mathrm{~W}$ total $)$ to maintain $10 \mathrm{~h}$ of light per day.

To evaluate the influence of the hydrolysates on the seed germination, protrusion of rootlet and coleoptile was used as the criterion to determine the beginning of the elongation of the embryonic axis (BEWLEY and BLACK, 1994). This procedure was performed after $48 \mathrm{~h}$ of incubation and on the 4th, 7th and 9th days. At 7 and 9 days, a part of $50 \%$ was collected for dry biomass determination with the radicles and aerial parts separated. The collected parts were oven dried with forced air circulation at 48 ${ }^{\circ} \mathrm{C}$ for 3 days. Afterwards, the masses were weighed.

The Chemoface v1.6 software was used for experimental design, and the Graph Pad Prism
7.04 software to statistical analysis. Statistical data analysis was performed using t test, and a comparison of the means was carried out with Mann-Whitney test. All experiments were run in triplicate.

Structural characteristics of biomass and hydrolysate Lignocellulosic biomass characterization relative to proteins was conducted by elementary analysis (CHNS). To determine the contents of structural carbohydrates, concentrated acid hydrolysis was performed on the biomass milled according to the process of SLUITER et al. (2010). This procedure uses high performance liquid chromatography (HPLC) for analysis of the produced sugars.

Determination of the sugar concentration (glucose, xylose and arabinose) in the biomass and hydrolysate was performed using an HPLC (Shimadzu L202346), with an automatic sampler (SIL 10), control module (CBM-20A), LC pump (20AT) and refractive index detector (RID-10A). A Rezex RHMMonosaccharide $\mathrm{H}^{+}$column (Phenomenex brand), an ultrapure water mobile phase, a flow rate of $0.6 \mathrm{~mL}$ $\mathrm{min}^{-1}$ and an oven temperature of $85^{\circ} \mathrm{C}$ were used. The analytical curves were developed using standards $\left(\right.$ Sigma Aldrich ${ }^{\circledR}$ ) for glucose, xylose, arabinose and ethanol. The ash in the biomass was determined by calcination samples $(2 \mathrm{~g})$ at $570{ }^{\circ} \mathrm{C}$ for $120 \mathrm{~min}$.

Amino acid analysis was accomplished in an HPLC (Shimadzu/ LC-20AT) with Shim-pack Amino-Na column $(6.0 \mathrm{~mm}$ id $\mathrm{x} 100 \mathrm{~mm})$ and Trap ISC-30/S $0504(\mathrm{Na})$ column (4.0 mm id x $50 \mathrm{~mm})$. Gradient program was according to SHIMADZUCORPORATION (2008) with mobile phase A ( citrate buffer and $7 \%$ ethanol $\mathrm{pH} 3.0$ ); $\mathrm{B}$ (citrate buffer and $\left.\mathrm{H}_{3} \mathrm{BO}_{3} 0.20 \mathrm{~mol} \mathrm{~L}^{-1}\right) \mathrm{pH} 10$ and $\mathrm{C}\left(\mathrm{NaOH} 0.20 \mathrm{~mol} \mathrm{~L}^{-1}\right)$ $\mathrm{pH} 10$. The temperature was $60^{\circ} \mathrm{C}$ and $0.6 \mathrm{~mL} \mathrm{~min}^{-1}$ of flow. The standard amino acids were: Asp - Aspartic acid, Thr - Threonine, Ser - Serine, Glu - Glutamic Acid, Pro -Proline, Gly - glycine, Ala - Alanine, Cys- Cystine, Val - Valine, Met - Methionine, Lle - Isoleucine, Leu - Leucine, Tyr - Tyrosine, Phe Phenylalanine, His - Histidine e Lys - Lysine.

\section{RESULTS AND DISCUSSION}

\section{Hydrolysate characterization}

Elemental analysis carried out by CHNS showed that the tobacco stems and roots used as raw material to produce the hydrolysates presented carbon at over $40 \%$, nitrogen $<3 \%$ and sulfur at approximately $1 \%$, in both the root and stem (Table 1).

These elements are the most important chemical components for the formation of plant tissue, 
Table 1 - Elemental analysis of tobacco stem and root collected in farmers of the Rio Pardo Valley $(n=6)$.

\begin{tabular}{lcccc}
\hline Sample & CARBON (\%) & HIDROGEN (\%) & NITROGEN (\%) & SULFUR (\%) \\
\hline STEM 1 & 40.75 & 5.88 & 1.57 & 1.04 \\
ROOT 1 & 42.57 & 5.98 & 1.95 & 1.04 \\
STEM 2 & 41.01 & 6.03 & 2.44 & 1.06 \\
ROOT 2 & 41.07 & 6.13 & 2.08 & 1.10 \\
\hline
\end{tabular}

which includes the proteins and polysaccharides (MARTÍN JUÁREZ et al., 2016), that are separated into amino acids and sugars, respectively, which are the products of the breakdown due to alkaline or acidic hydrolysis.

Tobacco residues were analyzed for the presence of polysaccharides by hydrolysis with concentrated acid. Results of the hydrolysis indicated that approximately $60 \%$ of the stem and root harvested correspond to polysaccharides. These polysaccharides mainly contain glucose monomers, demonstrating that this residue is rich in cellulose. The sugar monomers found in the total biomass were glucose $(37.33 \pm 3.74 \%)$, xylose $(14.58 \pm 1.89 \%)$ and arabinose $(7.05 \pm 1.67 \%)$. Even though tobacco residue is rich in polysaccharides, after alkaline and acid hydrolysis lower levels $(\sim 30 \%)$ of the same monomers were obtained, which is expected when mild conditions of hydrolysis are used.

The sugars in the hydrolysate can be an important factor to plant growth, since, according to Galdiano Júnior et al. (GALDIANO JÚNIOR et al., 2013) in a study with Cattleya violacea (Kunth), the sugars are sources of energy during respiration; and therefore, act as precursors for the biosynthesis of structural and functional components such as oligosaccharides, amino acids and other molecules.

Hydrolysate can be an exogenous supply of sugar and thus contributes to the starch and sucrose reserves in the seedling and accelerate physiological adaptation. According to ACKERSON (1985) exogenous glucose is important for the development of immature seeds, and he showed that glucose was more effective than sucrose in the growth of seeds cultured in vitro. In addition, SUN et al. (2018) indicated that sugar solution concentration is important for germination once the sugar application could improve the initial germination and inhibit lipid breakdown and to mitigate oxidative damages in the germination.

Glucose concentrations may cause stimulation in germination and development in corn seeds, and in high concentrations may retard development due to the formation of abscisic acid (SIDDIQUI et al., 2020).

According to FERREIRA et al. (2007) amino acids has been applied for several years in different cultures around the world and in Brazil it is not different. The benefits in the use of these products are reported by technicians and producers. There are few scientific studies that prove their effectiveness, as example the application of fertilizers masks the amino acids effect in plant growth or germination.

There are several hypotheses about the effects and functions of amino acids in the development of plants, such as changes to protein synthesis, intermediary compounds of endogenous plant hormones, effects on nutrients and agrochemicals, higher resistance to hydric stress, and tolerance of higher temperatures and disease and pest attack. However, there are doubts about the absorption of exogenous amino acids for improving plant metabolism (CARVALHO et al., 2013; HILDEBRANDT et al., 2015; SOUZA \& PERES, 2016; LIU et al., 2018).

In the hydrolysates produced, the following major free amino acids were reported: asparagine, glutamine, alanine, phenylalanine and lysine, as shown in table 2 . The root hydrolysates presented lower amino acid composition. It is observed that lysine is formed primarily from the acid attack of the tobacco stem. The analysis of the hydrolysate obtained by alkaline attack of the same stem also revealed the presence of glutamine.

Among the amino acids identified, the most important is asparagine, which is one of the main nitrogen-fixing and transporting agents of nitrogen in the xylem sap; also, glutamine was present and is important in transporting organic nitrogen, influencing phytomass and plant productivity (FERREIRA et al., 2002; LEA et al., 2007).

\section{Hydrolysate application}

Rice seed germination

Root and stem hydrolysates showed germination rates up to $94 \%$ after $48 \mathrm{~h}$ of 
Table 2 - Amino acid content reported in tobacco root and stem hydrolysates.

\begin{tabular}{|c|c|c|c|c|}
\hline \multirow[t]{2}{*}{ Amino acids $\left(\mu \mathrm{mol} \mathrm{mL} L^{-1}\right)$} & \multicolumn{2}{|c|}{ 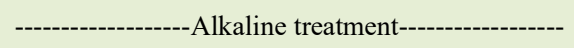 } & \multicolumn{2}{|c|}{ 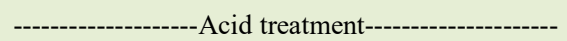 } \\
\hline & HS & HR & HS & HR \\
\hline Aspartic acid & 3.33 & 0.99 & 9.95 & 2.23 \\
\hline Threonine & 0.16 & 0.21 & 1.25 & 0.31 \\
\hline Serine & 1.08 & 0.82 & 5.73 & 0.55 \\
\hline Glutamic Acid & 10.76 & n.d. & n.d. & n.d. \\
\hline Proline & n.d. & n.d. & n.d. & n.d. \\
\hline Glycine & 0.70 & 0.43 & 0.73 & 0.37 \\
\hline Alanine & 3.32 & 1.40 & 4.16 & 1.41 \\
\hline Cystine & 0.26 & 0.13 & 0.71 & 0.33 \\
\hline Valine & 0.11 & 0.18 & 0.34 & 0.25 \\
\hline Methionine & 0.63 & 0.15 & 1.07 & 0.48 \\
\hline Isoleucine & 0.51 & 0.37 & 2.10 & 1.45 \\
\hline Leucine & 0.82 & 0.37 & 0.99 & 0.65 \\
\hline Tyrosine & 0.37 & 0.24 & 0.96 & 0.87 \\
\hline Phenylalanine & 1.73 & 1.13 & 3.17 & 1.16 \\
\hline Histidine & 0.02 & n.d. & 0.02 & n.d. \\
\hline Lysine & 17.38 & 4.60 & 19.54 & 3.52 \\
\hline Arginine & n.d. & n.d. & n.d. & n.d. \\
\hline Total & 41.18 & 11.02 & 50.72 & 13.58 \\
\hline
\end{tabular}

Where: n.d. $=<$ LD: below limit of detection; HS - stem hydrolysate and HR - root hydrolysate.

incubation. These results showed a positive influence in the germination of rice seeds, as the results were significantly different those of the water blank $(\mathrm{p}<0.05)$.

The influence of the hydrolysates on the rootlets and aerial parts mass of rice seeds also evaluated. A positive effect on rice germination observed by the rootlets and aerial part masses (g) are present in the table 3 . The hydrolysate obtained from acid treatment showed better results from both, root and stem tobacco residues. This finding may be due to the higher rate of protein hydrolysis, forming amino acids that improve nutrition (DALIR and KHOSHGOFTARMANESH, 2014).

In addition, it is observed that the variables (incubation time, hydrolysate dilution and hydration volume) did not have a significant effect on the germinated mass.

\section{Corn seed germination}

The corn seed was tested with the same variables as in the rice seed study. After two days, in $75 \%$ of the experiments, over $96 \%$ germination taxes were achieved. Compared to the water blank

Table 3 - $p$ values from the means of the rice mass (aerial part and root) obtained from hydration with tobacco hydrolysate (acid and alkaline) using the Mann Whitney test with software Graph Pad Prism 7.04.

\begin{tabular}{lccc}
\hline Hydrolysate & Treatment & Aerial part of rice & Root of rice \\
\hline \multirow{2}{*}{ HR } & & 0.0404 & 0.9591 \\
& Alkaline & 0.0002 & 0.6657 \\
HS & Acid & 0.2786 & 0.3823 \\
& Alkaline & 0.0011 & 0.7984 \\
\hline
\end{tabular}


there was no significance in the germination taxes $(\mathrm{p}>0.05)$. Therefore, it was observed that the results were similar for the control and hydrolysates (from acid or alkaline attack), not demonstrating that they are more adequate for the germination.

Regarding the influence of the hydrolysates on the rootlets and aerial parts mass of corn seeds with controlled variables in the experimental design, it was observed that the incubation time was significant $(p<0.05)$ to seedling growth as well results obtained with rice seed. Results indicated that the acid treatment promoted more growth (Figure 1A) and was associated with more diluted hydrolysate and more volume in the hydration, which is better (Figure 1B).

The total mass obtained using the hydrolysates was larger than those from water treatment $(\mathrm{p}<0.05)$. There was a significant difference between mass production with hydrolysates obtained by acid treatment as shown in the table 4 . The better hydrolysate for seedling development was obtained from tobacco stem after acid treatment.

Thus, the results obtained from tobacco stem, hydrolyzed by acid treatment, were shown to be better for nutrition during germination. The mass

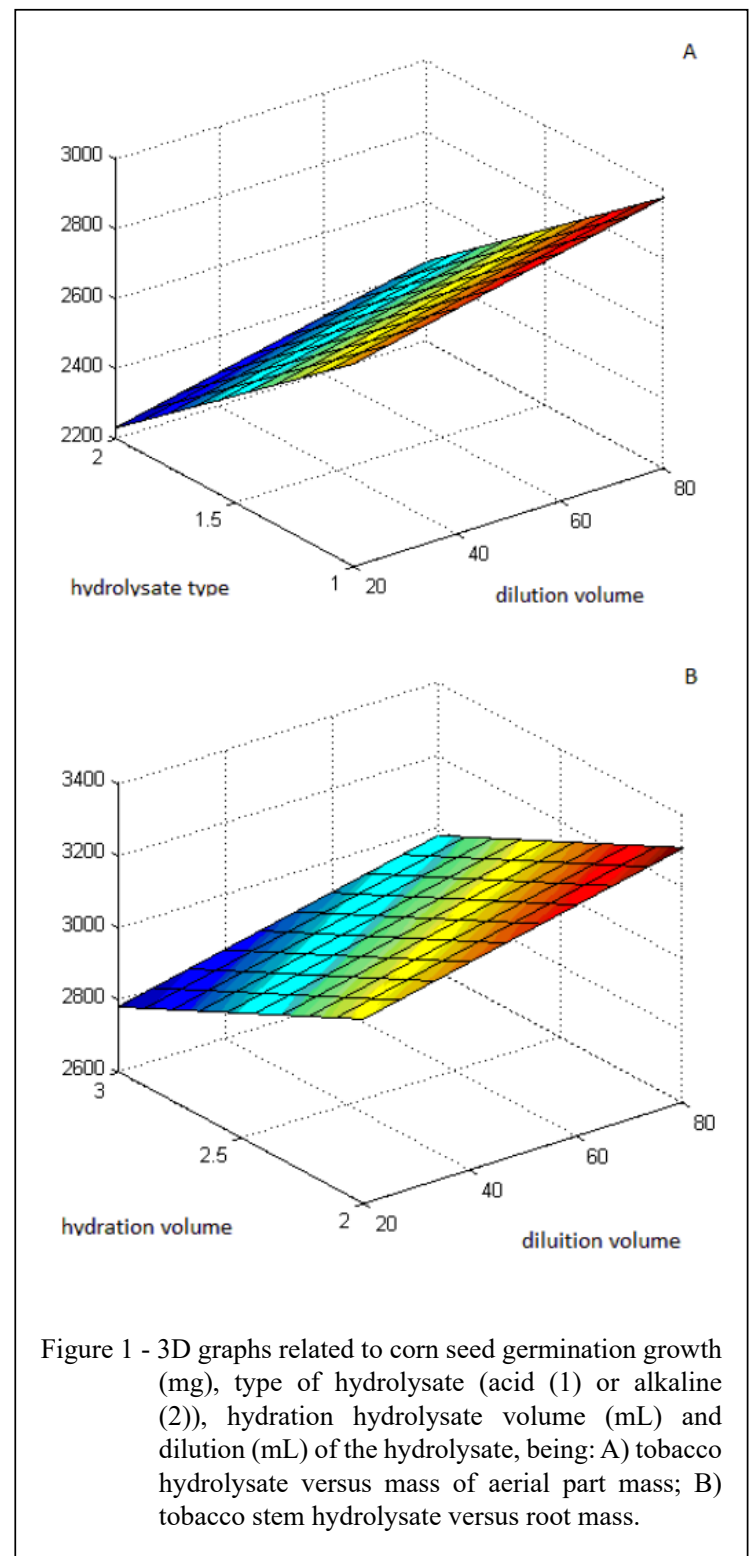

Ciência Rural, v.50, n.8, 2020. 
Table 4 - $p$ values from means of the corn mass (aerial part and root) obtained from hydration with tobacco hydrolysate (acid and alkaline) using the tobacco stem and root hydrolysates using the Mann Whitney test with software Graph Pad Prism 7.04.

\begin{tabular}{|c|c|c|c|}
\hline \multirow[t]{2}{*}{ Hydrolysate } & \multirow[t]{2}{*}{ Treatment } & \multicolumn{2}{|c|}{------------------------p value---------------------- } \\
\hline & & Aerial part & Rootlets \\
\hline \multirow{2}{*}{ HR } & Alkaline & 0.3823 & 0.9591 \\
\hline & Acid & 0.0207 & 0.0281 \\
\hline \multirow{2}{*}{ HS } & Alkaline & 0.7209 & 0.7209 \\
\hline & Acid & 0.0281 & 0.0281 \\
\hline
\end{tabular}

HS - stem hydrolysate and HR - root hydrolysate.

obtained at the same time was significantly bigger. For aerial parts, we reported $41.4 \%$ (hydrolysate root) and $44.5 \%$ (hydrolysate stem) more mass than those obtained from water hydration; for rootlets, we reported $56.3 \%$ (hydrolysate root) and $55.1 \%$ (hydrolysate stem) more mass.

In the context of this research, it was not possible to identify an inhibitory action on the germination caused by the hydrolysates, since the results were equal to or better than those obtained with the control (water), considering the initial germination period (embryo and protrusion of the rootlet) and the growth of the seedling.

Based on the evidence that the hydrolysate tobacco stem contributed with different amino acids, it can be seen that these hydrolysates have the potential to act as growth bioregulators (RATHORE et al., 2009; SCALON et al., 2009; SELANON et al., 2014).

\section{CONCLUSION}

The hydrolysates obtained by acid and alkali treatment of the tobacco stem and root have the potential to stimulate the germination of rice and corn seeds. The use of the hydrolysates in the germination of the rice showed that there is acceleration of germination in the first two days; however, the seedlings formed have the same mass as those obtained with hydration in water. It was reported that the hydrolysate obtained by acid treatment of the tobacco root or stem shows the best results for corn seedling development compared to those obtained by alkali treatment. In relation to elongation of the embryonic axis of corn seed in the first $48 \mathrm{~h}$, a difference was not observed between hydrolysates and water. Hydrolysates are not detrimental to plant development, and it is possible to improve the results with mixtures of hydrolysates applied in germination or in other periods of development.

\section{ACKNOWLEDGEMENTS}

We would like to thank the financial support of the Conselho Nacional de Desenvolvimento Científico e Tecnológico - CNPq for granting the research productivity scholarship (R.C.S.S - 310228/2019-0), Ministério de Ciência, Tecnologia, Inovação e Comunicação - MCTIC (01.0144.00/2010) and Secretaria de Desenvolvimento Econômico, Ciência e Tecnologia do Rio Grande do Sul SDECT- RS (209-2551/14-1) for financial support and Coordenação de Aperfeiçoamento de Pessoal de Nível Superior CAPES for research databases availability.

\section{DECLARATION OF CONFLICT OF} INTERESTS

The authors declare no conflict of interest. The founding sponsors had no role in the design of the study; in the collection, analyses, or interpretation of data; in the writing of the manuscript, and in the decision to publish the results.

\section{AUTHORS' CONTRIBUTIONS}

All authors were involved in the design of experiments, study, and data analysis.

\section{REFERENCES}

ABBOTT, L. K. et al. Potential roles of biological amendments for profitable grain production - A review. Agriculture, Ecosystems \& Environment, v.256, p.34-50. 2018. Available from: <http:// www.sciencedirect.com/science/article/pii/S0167880917305571>. Accessed: Nov. 24, 2019. doi: 10.1016/j.agee.2017.12.021.

ACKERSON, R. Invertase activity and abscisic acid in Relation to carbohydratesStatus in developing soybean reproductive structures 1. Crop Science, v.25, n.4, p.615-618. 1985. Accessed: Nov. 10, 2019. doi: 10.2135/cropsci1985.0011183X 002500040009x.

BEWLEY, J. D.; BLACK, M. Seeds. In: (Ed.). Seeds: Springer, 1994. p.1-33. 
CARVALHO, F. S. et al. Life cycle assessment of biodiesel production from solaris seed tobacco. Journal of Cleaner Production, v.230, p.1085-1095. 2019. Available from: $<$ https://www.scopus.com/inward/record.uri?eid=2-s2.085066134793\&doi=10.1016\%2fj.jclepro.2019.05.177\&partnerI $\mathrm{D}=40 \& \mathrm{md} 5=2 \mathrm{~d} 4 \mathrm{cf} 15 \mathrm{a} 156 \mathrm{cbdc} 064833 \mathrm{be} 86 \mathrm{deb} 0049>$. Accessed: Nov. 10, 2019. doi: 10.1016/j.jclepro.2019.05.177.

CARVALHO, T. C. D. et al. Influence of biostimulants on germination and seedling development of Phaseolus vulgaris in water restriction. Revista de Ciências Agrárias, v.36, n.2, p.199205. 2013. Accessed: Nov. 24, 2019.

COLLA, G. et al. Protein hydrolysates as biostimulants in horticulture. Scientia Horticulturae, v.196, p.28-38. 2015. Available from: $<$ http://www.sciencedirect.com/science/article/pii/ S0304423815301564>. Accessed: Nov. 24, 2019. doi: 10.1016/j. scienta.2015.08.037.

COLLA, G. et al. Biostimulant action of a plant-derived protein hydrolysate produced through enzymatic hydrolysis. Frontiers in Plant Science, v.5, n.448, p.448. 2014. Available from: <https:// www.frontiersin.org/article/10.3389/fpls.2014.00448>. Accessed: Nov. 24, 2019. doi: 10.3389/fpls.2014.00448.

DALIR, N.; KHOSHGOFTARMANESH, A. H. Symplastic and apoplastic uptake and root to shoot translocation of nickel in wheat as affected by exogenous amino acids. J Plant Physiol, v.171, n.7, p.531-6. 2014. Available from: <https://www.ncbi.nlm.nih.gov/ pubmed/24655389>. Accessed: Nov. 24, 2019. doi: 10.1016/j. jplph.2013.12.011.

DU JARDIN, P. The Science of Plant Biostimulants-A bibliographic analysis, Ad hoc study report: European Commission 2012.

DU JARDIN, P. Plant biostimulants: definition, concept, main categories and regulation. Scientia Horticulturae, v.196, p.3-14. 2015. Accessed: Nov. 24, 2019. doi: 10.1016/j.scienta.2015.09.021.

FERREIRA, L. A. et al. Treatment of corn seeds with biostimulant and fertilizer. Revista Brasileira de Sementes, v.29, n.2, p.80-89. 2007. Accessed: Mar. 28, 2018. doi: 10.1590/S010131222007000200011

FERREIRA, V. M. et al. Nitrogen metabolism associated to water deficit and its recovery in maize genotypes. Ciência Rural, p.13-17. 2002. Accessed: Oct. 27, 2019. doi: 10.1590/S010384782002000100003

FORNASIER, F. et al. Biodiesel production from energy Tobacco. Orbital, v.10, n.2, p.123-132. 2018. Available from: $<$ https://www. scopus.com/inward/record.uri?eid=2-s2.0-85044839363\&doi=10. $17807 \%$ 2forbital.v10i2.1120\&partnerID $=40 \& \mathrm{md} 5=8 \mathrm{fac} 312584 \mathrm{e} 5$ a10dec6d3c52cf571dc9>. Accessed: Oct. 27, 2019. doi: 10.17807/ orbital.v10i2.1120.

GALDIANO JÚNIOR, R. F. et al. Initial development and in vitro growth of Cattleya violacea (Kunth) Rolfe in different sucrose concentrations. Acta Amazonica, p.127-134. 2013. Accessed: Nov. 24, 2019. doi: 10.1590/S0044-59672013000200001.

HALPERN, M. et al. Chapter Two - The use of biostimulants for enhancing nutrient uptake. In: SPARKS, D. L. (Ed.). Advances in Agronomy: Academic Press, v.130, 2015. p.141-174. (Advances in Agronomy). ISBN 0065-2113.
HILDEBRANDT, TATJANA M. et al. Amino acid catabolism in plants. Molecular Plant, v.8, n.11, p.1563-1579. 2015. Available from: <http://www.sciencedirect.com/science/article/pii/ S1674205215003664>. Accessed: Nov. 24, 2019. doi: 10.1016/j. molp.2015.09.005.

KIST, B. B. et al. Brazilian Tobacco Year Book. Santa Cruz do Sul: Editora Gazeta Santa Cruz, 2018. 132 Available from: $<$ http:/www.editoragazeta.com.br/produto/anuario-brasileiro-dotabaco-2018/>. Accessed: Nov. 24, 2019.

LEA, P. J. et al. Asparagine in plants. Annals of Applied Biology, v.150, n.1, p.1-26. 2007. Accessed: Mar. 28, 2018. doi: 10.1111/j.1744-7348.2006.00104.x.

LIU, H. et al. Production of Free Amino Acid and Short Peptide Fertilizer from Rapeseed Meal Fermentation Using Bacillus flexus NJNPD41 for Promoting Plant Growth. Pedosphere, v.28, n.2, p.261-268. 2018. Available from: <http://www.sciencedirect.com/ science/article/pii/S1002016018600128>. Accessed: Nov. 24, 2019. doi: 10.1016/S1002-0160(18)60012-8.

LUCINI, L. et al. The effect of a plant-derived biostimulant on metabolic profiling and crop performance of lettuce grown under saline conditions. Scientia Horticulturae, v.182, p.124-133. 2015. Available from: <http:/www.sciencedirect.com/science/article/pii/ S0304423814006517>. Accessed: Nov. 24, 2019. doi: 10.1016/j. scienta.2014.11.022.

MARTÍN JUÁREZ, J. et al. Saccharification of microalgae biomass obtained from wastewater treatment by enzymatic hydrolysis. Effect of alkaline-peroxide pretreatment. Bioresource Technology, v.218, p.265-271. 2016. Available from: $<$ http://www. sciencedirect.com/science/article/pii/S096085241630904X>. Accessed: Nov. 24, 2019. doi: 10.1016/j.biortech.2016.06.087.

MASONDO, N. A. et al. Influence of biostimulants-seed-priming on Ceratotheca triloba germination and seedling growth under low temperatures, low osmotic potential and salinity stress. Ecotoxicology and Environmental Safety, v.147, p.43-48. 2018. Available from: $<$ http://www.sciencedirect.com/science/article/pii/ S0147651317305134>. Accessed: Nov. 24, 2019. doi: 10.1016/j. ecoenv.2017.08.017.

MOTGHARE, K. A. et al. Comparative study of different waste biomass for energy application. Waste Manag, v.47, n.Pt A, p.40-5. 2016. Available from: <https://www.ncbi.nlm.nih.gov/ pubmed/26303650>. Accessed: Nov. 24, 2019. doi: 10.1016/j. wasman.2015.07.032.

QING, Q. et al. Comparison of alkaline and acid pretreatments for enzymatic hydrolysis of soybean hull and soybean straw to produce fermentable sugars. Industrial Crops and Products, v.109, p.391-397. 2017. Available from: <http://www.sciencedirect.com/ science/article/pii/S0926669017305824>. Accessed: Nov. 24, 2019. doi: 10.1016/j.indcrop.2017.08.051.

RATHORE, S. et al. Effect of seaweed extract on the growth, yield and nutrient uptake of soybean (Glycine max) under rainfed conditions. South African Journal of Botany, v.75, n.2, p.351-355. 2009. Accessed: Mar. 28, 2018. doi: 10.1016/j. sajb.2008.10.009.

SANTOS, V. M. D. et al. Use of biostimulants on the growth of Zea mays L plants. Revista Brasileira de Milho e Sorgo, v.12, n.3, p.307-318. 2014. Accessed: Nov. 24, 2019. 
SCALON, S. D. P. Q. et al. Seed germination and initial growth of Campomanesia adamantium Camb seedlings: effects of washing, temperature and biostimulant. Revista Brasileira de Sementes, v.31, n.2, p.96-103. 2009. Available from: <https://www.scielo. $\mathrm{br} / \mathrm{scielo}$.php? pid=S0101-31222009000200011\&script $=\mathrm{sci}$ abstract>. Accessed: Mar. 28, 2018.

SELANON, O. et al. Utilization of Jatropha curcas seed cake as a plant growth stimulant. Biocatalysis and Agricultural Biotechnology, v.3, n.4, p.114-120. 2014. Accessed: Nov. 24, 2019. doi: 10.1016/j.bcab.2014.08.001.

SHIMADZU-CORPORATION. Shimadzu High-Performance Liquid Chromatograph Prominence. Amino Acid Analysis System Supplementary Manual. . Japan 2008.

SIDDIQUI, H. et al. Glucose: Sweet or bitter effects in plants-a review on current and future perspective. Carbohydrate Research, v.487, p.107884. 2020. Available from: <http://www.sciencedirect. com/science/article/pii/S0008621519305142> . Accessed: Nov. 24, 2019. doi: 10.1016/j.carres.2019.107884.

SLUITER, J. B. et al. Compositional analysis of lignocellulosic feedstocks. 1. Review and description of methods. Journal of agricultural and food chemistry, v.58, n.16, p.90439053. 2010. Available from: <https://www.ncbi.nlm.nih.gov/ pubmed/20669951>. Accessed: Nov. 22, 2019. doi: 10.1021/ jf1008023.
SOUZA, L. R. D.; PERES, F. S. B. Use of bio-fertilezers based on amino acids to grow Eucalyptus dunnii seedlings. Pesquisa Florestal Brasileira, v.36, n.87, p.211-218. 2016. Available from: <https://redib.org/Record/oai articulo1076860-use-bio-fertilezers-based-amino-acids-groweucalyptus-dunnii-seedlings $>$. Accessed: Nov. 24, 2019. doi: 10.4336/2016.pfb.36.87.1127.

SUN, J. et al. Exogenous gibberellin weakens lipid breakdown by increasing soluble sugars levels in early germination of Zanthoxylum seeds. Plant Science, v.280, p.155-163. 2018. Available from: $<\mathrm{http}: / / \mathrm{www}$. sciencedirect.com/science/article/pii/ S016894521830579X>. Accessed: Nov. 24, 2019. doi: 10.1016/j. plantsci.2018.08.013.

SUNCHEM. Solaris: our multi-purpose crop. 2018. Avaialble fromt: <http://www.sunchem.nl/>. Accessed: Nov. 24, 2019.

UGOLINI, L. et al. Production of an enzymatic protein hydrolyzate from defatted sunflower seed meal for potential application as a plant biostimulant. Industrial Crops and Products, v.75, p.1523. 2015. Available from: $<$ http://www.sciencedirect.com/science/ article/pii/S0926669014007134>. Accessed: Nov. 24, 2019. doi: 10.1016/j.indcrop.2014.11.026.

WHO, W. H. O. WHO Framework Convention on Tobacco Control. 2018. Avaialble from: <http://www.who.int/fctc/cop/ about/en/>. Accessed: Nov. 24, 2019. 